\title{
Viscosupplementation in prevention and treatment of the degenerative joint disease
}

\section{Wiskosuplementacja w zapobieganiu i leczeniu zmian zwyrodnieniowych stawów}

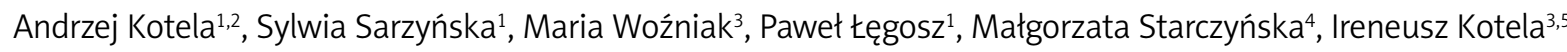 \\ ${ }^{1}$ Department of Orthopaedics and Traumatology of Musculoskeletal System, $1^{\text {st }}$ Faculty of Medicine, Medical University of Warsaw, \\ Warsaw, Poland \\ Head of the Department: Prof. Paweł Małdyk MD, PhD \\ ${ }^{2}$ Health Protection Faculty, Almamer University, Warsaw, Poland \\ Head of the Faculty: Joanna Jasińska MD, Prof. AU \\ ${ }^{3}$ Department of Orthopaedic Surgery and Traumatology, Central Clinical Hospital for the Ministry of Interior, Warsaw, Poland \\ Head of the Department: Ireneusz Kotela MD, PhD, Prof. JKU \\ ${ }^{4}$ Department of Manual Therapy, Institute of Physiotherapy, Faculty of Medicine and Health Science, Jan Kochanowski University, \\ Kielce, Poland \\ Head of the Department: Zbigniew Śliwiński MD, PhD, Prof. JKU \\ ${ }^{5}$ Department of Rehabilitation in Disease of the Locomotor, Institute of Physiotherapy, Faculty of Medicine and Health Science, \\ Jan Kochanowski University, Kielce, Poland \\ Head of the Department: Ireneusz Kotela MD, PhD, Prof. JKU
}

Medical Studies/Studia Medyczne 2015; 31 (4): 300-306

Key words: osteoarthritis, hyaluronic acid, viscosupplementation.

Słowa kluczowe: choroba zwyrodnieniowa stawów, kwas hialuronowy, wiskosuplementacja.

\begin{abstract}
Osteoarthritis (OA) is one of the most common musculoskeletal disorders. It limits patients' functionality and life satisfaction significantly. Although there are numerous types of therapy, the success rate of conservative treatment is limited, and it is often necessary to introduce surgical treatment. Therefore, new effective methods of therapy for OA are being tested and submitted. Endogenous hyaluronic acid (HA) is a natural ingredient of many tissues in the human organism, including synovial fluid. Viscosupplementation with the usage of HA is a relatively new method for treating degenerative joint changes. By virtue of its good safety profile and simplicity of application, it is increasingly used as an alternative or addition to classic conservative treatment. In this work, we attempted to summarise the current state of knowledge of HA usage in OA treatment based on literature.
\end{abstract}

\section{Streszczenie}

Choroba zwyrodnieniowa stawów jest częstym schorzeniem układu mięśniowo-szkieletowego. Niestety skuteczność leczenia zachowawczego zmian zwyrodnieniowych stawów jest ograniczona i często konieczne bywa leczenie chirurgiczne. W związku z tym podejmowane są próby wprowadzenia nowych metod terapii choroby zwyrodnieniowej stawów. Endogenny kwas hialuronowy jest naturalnym składnikiem wielu tkanek w organizmie ludzkim, w tym płynu stawowego. Wiskosuplementacja z wykorzystaniem preparatów kwasu hialuronowego jest stosunkowo nową metodą miejscowego leczenia zmian zwyrodnieniowych. Ze względu na dobry profil bezpieczeństwa i łatwość aplikacji jest coraz częściej wykorzystywana jako alternatywa lub wzbogacenie klasycznych terapii zachowawczych. W pracy podjęto próbę podsumowania aktualnej wiedzy na temat stosowania kwasu hialuronowego w leczeniu zmian zwyrodnieniowych stawów na podstawie aktualnego piśmiennictwa.

\section{Introduction}

Osteoarthritis (OA) is considered to be one of the most common diseases of the musculoskeletal system. According to estimates, in the world population this matter concerns the majority of patients over 70 years old [1], more often women and obese individuals [2,
3]. Taking into account the wide epidemiology of this disorder and the considerable decrease in sufferers' quality of life, new research is being conducted to find original and effective therapeutic solutions to prevent the occurrence of the disease or slow down its progress. Currently used treatment methods are divided into two categories: conservative (pharmacological 
and nonpharmacological) and surgical. Firstly, every case should be treated with a conservative method. There are many possibilities of nonsurgical and pharmacological treatment, including among others viscosupplementation.

Viscosupplementation that uses hyaluronic acid (HA) specimens is a relatively new method for treating degenerative joint changes. By virtue of its good safety profile and simplicity of application, it is increasingly used as the alternative or addition for classic conservative therapy. It is suggested that by decreasing pain it allows a reduction in the dosage of analgesics, both nonsteroidal and opioid, and it delays the time when replacing the affected joint or introducing another surgical procedure is necessary [4]. It has been shown that using HA postpones total knee arthroplasty by 2.2 years on average [5].

The aim of this paper was to summarise the current knowledge concerning the use of $\mathrm{HA}$ in OA treatment.

\section{General remarks regarding hyaluronic acid}

Karl Meyer and his assistant, John Palmer, are considered to be the discoverers of HA because they were the first to isolate this substance from the eyeball of an ox in 1934. The etymology of the substance that they discovered partly comes from the presence of uronic acid in the molecule. The prefix in the word hyaluronic reflects a prime tissue from which the acid was isolated because the Greek word hyalos means vitreous humour of the eyeball [6]. Hyaluronic acid is an endogenous polysaccharide occurring in vertebrates in extra cellular matrix (ECM) of many mature tissues. The largest amount of it is found in skin, epidermis, synovial fluid, articular cartilage, and umbilical cord [7].

Endogenous HA is a natural ingredient of many tissues in the human organism including synovial fluid (produced by chondrocyte and synovial membrane cells). It has been shown that in the course of various pathological processes within joints, mainly with inflammatory foundation, the concentration of HA in synovial fluid changes, which could intensify their dysfunction. In the early 1960s, Balasz and Denlinger [8] introduced the idea of supplementation with exogenous HA to improve synovial fluid properties and to decrease pain ailments. Shortly afterwards there were the first studies on animal models and attempts to treat racehorses. In 1997, HA received Food and Drug Administration (FDA) acceptance to treat people. Currently, HA is used mainly for OA of the knee because there is the greatest scientific evidence and literature confirming the legitimacy of this kind of action. More and more efforts are being made to use this therapy within other joints.

From a biochemical point of view, HA is a biopolymer that contains molecules of glucuronic acid and $\mathrm{N}$-acetyl glucosamine that are connected by $\beta-1,4$ glycosidic bonds [9]. Under in vivo conditions the molecules of HA are highly polarised, whereby they bind well with water. This results from the complete ionisation of all carboxyl groups, both glucuronic acid and N-acetyl glucosamine [10]. The molecular weight and length of acid molecules depend on the number of polysaccharide molecules in the chain (10 million - 25 thousand disaccharide subunits). The average molecular weight of acid molecules ranges from 6 to $12 \mathrm{MDa}$ [11], depending on the localisation and state of tissues. It has been observed that in the synovial fluid of healthy joints the weight of polysaccharide is around $7 \mathrm{MDa}$, and in diseased joints it is $4.8 \mathrm{MDa}$ [12]. Many kinds of cells have the ability to biosynthesise HA - among others: fibroblasts, synovial cells, endothelial cells, and oocytes. Catabolism of the substance happens quickly - in from $12 \mathrm{~h}$ to a few days. According to data, during $24 \mathrm{~h} \mathrm{1/3}$ of the total amount of acid in the organism undergoes the exchange and degradation (that means about 3-4 $\mathrm{g}$ for a person who weighs $60 \mathrm{~kg}$ ). The duration of acid in the tissues depends on, to a small extent though, molecular weight. Moreover, it has been shown that inflammatory conditions increase the degree of HA degradation [13].

In the joints, endogenous HA is a natural component of synovial fluid, and it works both mechanically and biologically [14]. Hyaluronic acid increases the viscosity and elasticity of the synovial fluid that helps it to work as the "lubricant" (protection during slow movements) and as the shock-absorbing agent (protection during sharp movements) [15]. Its physiological role is connected with maintaining the integrity of the cartilage by lubricating and influencing the metabolism of chondrocytes [16]. The two main substances produced by synovial cells are lubricin and HA. They reduce the mutual friction of the articular surface and, therefore, they inhibit the progression of degenerative changes $[17,18]$.

The exact mechanism of activity of $\mathrm{HA}$ in the joints is unknown. The following theories are the most popular: 1) the role in restoring the viscoelastic properties of synovial fluid, 2) the stimulation of chondrocyte to produce endogenous acid, 3) the analgesic effect exerted by acting on nociceptive receptors, 4) reducing the inflammatory process, and 5) stimulating the growth of chondrocytes, inhibition of their apoptosis, and the stimulation of collagen synthesis [19]. There are scientific data confirming each of the listed theses [20]. It has also been demonstrated that HA decreases the level of proinflammatory cytokines in the synovial fluid of patients treated for OA (prostaglandins, cytokines, CAMP, and others) [21-24]. Moreover, it directly influences the leukocytes' activity by decreasing their proliferation, migration, adherence, and phagocytosis. In vitro research also confirms the ability of HA to stimulate the endogenous production of HA and other glycosaminoglycans [25]. 
For the medical purposes and research, it can be obtained by isolation from the tissues or by advanced biomolecular methods that use the natural bacterial enzyme systems for production (strains of bacteria Streptococcus species are the most commonly used). It should be noted that currently used specimens with intra-articular HA differ from one another primarily in concentration and molecular weight, which remain in correlation with each other. According to EULAR [26] it is possible to distinguish HA specimens with low molecular weight (LMW) HA (molecular weight: 0.5-0.73 m Daltons) and intermediate molecular weight (IMW) HA (molecular weight $0.8-2.0 \mathrm{~m}$ Daltons). Specimens at $1 \%$ concentration have a low molecular weight while the specimens at $2.2 \%$ have an intermediate molecular weight. For instance, the specimen Biolevox HA from Biovico is a medium-molecule specimen (with molecular weight: 1.5-2 $\mathrm{m} \mathrm{Da}$ ) and acid concentration $2.2 \%$. Furthermore, in one pre-filled syringe there is $44 \mathrm{mg}$ of HA. This division is important because, according to scientific studies, specimens of HA with different molecular weights differ from one another in terms of therapeutic effect achieved in various joints. Viscoelasticity results that have been obtained show that the viscoelastic properties of LMW HA specimens are inferior to IMW HA. The effectiveness of different specimens may also be affected by the supply amount of HA. The specimens with $1 \%$ concentration in one $2-\mathrm{ml}$ pre-filled syringe contain $20 \mathrm{mg}$ of the HA, which throughout five injections gives $100 \mathrm{mg}$. In the case of specimens with, for example, $2.2 \%$ concentration, there is $44 \mathrm{mg}$ of the HA in one pre-filled syringe, which throughout five injections totals $220 \mathrm{mg}$ of HA. The studies suggest that when the molecular weight of HA increases, the duration of the positive effects of its application is extended [27].

It should be noted that the number of acid injections should depend on the joint size and primarily on the specimen kind and its molecular weight [28]. Acids having a linear structure possess a shorter halflife than acids with a large number of crosslinks. One of the hypotheses explaining the mechanism of HA activity assumes that its effectiveness depends on the duration of the contact of the specimen with structures within the joint (especially the cartilage and the synovium) [29].

Rare but present side effects of HA usage should also be discussed. Among the systemic ones, generalised allergic reactions are acknowledged. Local, more frequent side effects than systemic should include local inflammatory reactions with various intensities. The local symptoms may occur in $1-3 \%$ of patients [30]. Pain ailments and pruritus usually disappear within three days. There is the evidence suggesting that with the decrease of the molecular weight of the specimen the risk of side effects of their use also decreases [30, 31].

\section{Medical applications of hyaluronic acid}

In 1997 the FDA gave permission to use HA in the treatment of people. The range of its application at present is wide, and HA specimens are used in many medical specialties. In aesthetic medicine and dermatology the main use of this preparation is filling broadly defined skin imperfections, mainly of the face, including the elimination of wrinkles on different locations and correction of facial features. The acid is also used in lip-filling and lip augmentation [32]. From a dermatological and a variety of treatment specialties point of view, the acid and its derivatives are a very important part of wound healing and skin regeneration $[33,34]$. The effectiveness in wound healing was also shown in patients after excision of tonsils. Moreover, the usage of HA decreased postsurgical pain in this group of patients [35]. Another application of hyaluronic acid specimens in otolaryngeal practice is associated with supporting the regeneration process of perforated eardrum [36]. Hyaluronic acid is also applied in ophthalmology and other medical fields.

\section{The role of hyaluronic acid in degenerative arthritis treatment}

Injections of HA are a commonly used method for treating OA of the knee [37, 38]. In 2012 in the American College of Rheumatology (ACR) guidelines for knee OA treatment, there was a recommendation to use HA in patients whose results after primal treatment were unsatisfactory [39]. On the other hand, according to AAOS recommendations from 2013, the use of HA in medication of OA is decisively discouraged [40]. This is partly because of some studies that suggest that the use of such therapy is no more effective than placebo [41, 42]. Despite this, a significant percentage of available studies show that the use of acid injection is an effective treatment of this disease. In 2015, Henrotin et al. [43] published a paper that summarises the position of eight experts in the field of osteoarthritis in terms of viscosupplementation. One of the postulates on which the authors reached a consensus was the recognition of $\mathrm{HA}$ as an effective medication for osteoarthritis of the knee in mild to moderate degree. Furthermore, it was stated that this method is well tolerated both in OA of the knee and in other joints and it should not be recommended only as an alternative for other treatments that have failed. Meta-analysis showed HA efficacy in therapy for degenerative changes in the knee with a different range of severity - from high to minimal compared to the control group that received a placebo [44-47]. According to Bannuru's et al. [48], the positive effects of HA on OA (mainly pain ailments due to the lesions) remained for over 6 months after injection. The first effects were observed after 4 weeks, 
reaching the top effectiveness in the eighth week. As stated in the results, using the acid helped to achieve better outcome in patients than using paracetamol, non-stereoidal anti-inflammatory drugs (NSAIDs), and selective inhibitors COX-2 [49-51]. Other studies have not shown positive effects of this kind of therapy $[52,53]$. A meta-analysis published in 2014 compared the relative efficacy of HA and oral NSAIDs in treatment of OA of the knee. According to the results, HA therapy did not show increased effectiveness in improving the functionality, or reducing the pain or joint stiffness, in comparison with oral NSAIDs. Measured parameters after 4 weeks, 12 weeks, and at the end of the study were similar; in both cases improvement was moderate. The authors suggest that injections of HA may be an alternative to medication with oral analgesics, particularly in the elderly, because of the increased safety profile of drugs and lower risk of serious side effects in comparison to NSAIDs [54].

The large discrepancy in the results of research in this field, even in the case of systematic reviews and meta-analyses, is puzzling. Campbell et al. [55] have shown that, although the authors whose studies they analysed asked a similar research question, each of the research projects differed greatly in many methodological aspects. Therefore, it seems that it is precisely the methodological differences of individual papers that cause such a disparity in the results.

Treatment of OA of the other joints is documented in the literature to a much lesser degree. Despite the lack of substantial evidence, there are attempts to treat OA of different joints, in particular: hip, ankle, shoulder, and metacarpophalangeal joints (MCP) [56].

Due to the good results in the treatment of changes within the knee joint with HA, there have been attempts to treat $\mathrm{OA}$ of the glenohumeral joint with the use of HA specimens. The first studies are promising but equivocal. It has been demonstrated that the HA was effective in patients with healthy rotator cuff, but in the case of damage or coexistence of adhesive capsulitis effects were limited $[57,58]$. The study by Blaine's et al. [59] on a cohort of 660 patients showed that injections of HA are an effective therapeutic approach with a high safety profile, both in patients with isolated degenerative changes and in patients with concomitant pathologies in joint areas. The safety of repetitive HA injections has also been identified in the research conducted by Kwon et al. [60]. According to Colen's et al. [61] systematic review published in 2014, which took eight papers into account, using acid was the more effective method of decreasing pain ailments and improving patients' functionality. The authors indicate, however, that the results of applying the specimen have not reached the minimum clinically significant difference compared to placebo. In another study Colen et al. [62] suggest that currently there is no strong evidence to support HA preponder- ance over other conservative methods such as injections of corticosteroids (CST) or physiotherapy.

There are also attempts to treat $\mathrm{OA}$ of $\mathrm{MCP}$ joints with HA. According to the reports of experts from the Italian Society of Rheumatology, in prospective studies it was possible to observe the decrease of pain and improvement of functionality in MCP joints after application of HA specimens in comparison to the pre-treatment period. The experts indicate, however, that there is no evidence that the application of HA specimens has a greater significance than the use of placebo [63]. In agreement with Fuchs et al. [64], the use of injections with sodium derivatives of HA was effective in terms of reducing pain and improving functionality in the MCP joint. The study also contained a comparison between HA and steroids efficiency. It was shown that the effects of steroids occur much more quickly, but the durability of the effect after HA injections is longer. A slightly different position in terms of applying HA is presented by the ACR, whose guidelines do not recommend applying HA and corticosteroids in OA of MCP joints due to the insufficient amount of evidence proving effectiveness of these specimens [65]. Some of the research highlights the wider importance of HA in improving the functionality of affected joints and the more significant role of CST in reducing pain [66]. It should be noted that at the moment there are no studies showing the significance of acid injection with different molecular weights in the discussed joint [67].

In the case of degenerative changes in the hip joint, information on the use of HA is also divergent. According to the data, the use of HA was effective in mild and moderate degenerative changes in the hip joint, but in patients with severe changes, which qualify the patient for total hip replacement, the role of injection was on the placebo level [68, 69]. Also, Henrotin et al. [70] concluded that hyaluronic acid viscosupplementation could not be considered as an alternative to replacement in advanced hip osteoarthritis. A systematic review of Fernandez Lopez's et al. [71] literature suggests that the use of HA may be effective in terms of alleviating pain in patients with symptomatic OA of the hip joint; however, the authors' advise introducing this procedure after failure of other conservative treatment. Concurrently they underline the small amount of available literature that focuses on this subject and, in many cases, their methodological limitations. According to Qvistgaard et al. [72] the effects of using HA compared to injection of CST were worse, and they observed a low level of improvement in comparison to the moderate level after using CST. In their paper the authors also emphasise the higher costs of applying HA specimens compared to steroids. River's [73] research published in 2015 shows that a single HA injection with high molecular weight is an effective method for treating hip OA. The results 
were observed after a 3-month period starting from the beginning of the therapy, and remained for a year. To summarise, application data of HA in hip OA are divergent, but it appears that the therapy may be an alternative or complement to the classic methods of conservative treatment.

The specimens of HA were also used in patients with arthritis of the ankle joints. One research project demonstrated the effectiveness of acid in terms of decreasing pain and improving functionality in patients with I and II degree ankle joint OA on the Kellgren-Lawrence scale [74]. However, according to review by Cochrane from 2015 [75], available data are too discordant and unclear to make explicit conclusions. It is possible that using HA is well grounded in the case of insufficient patient response to commonly used analgesics.

\section{Conclusions}

Available literature on the effectiveness and appropriateness of applying hyaluronic acid preparations is ambiguous. However, it seems that HA injections are a potentially effective and safe method for treating mild or moderate changes in joints, and simultaneously they have a lower risk of side effects of therapy as compared to NSAIDs or CST. Viscosupplementation is, therefore, a valuable complement to the methods of conservative treatment of OA.

\section{Conflict of interest}

The authors declare no conflict of interest.

\section{References}

1. Loeser RF. Age-related changes in the musculoskeletal system and the development of osteoarthritis. Clin Geriatr Med 2010; 26: 371-86.

2. Reijman M, Pols HA, Bergink AP, et al. Body mass index associated with onset and progression of osteoarthritis of the knee but not of the hip: the Rotterdam Study. Ann Rheum Dis 2007; 66: 158-62.

3. Yusuf E, Nelissen RG, Ioan-Facsinay A, et al. Association between weight or body mass index and hand osteoarthritis: a systematic review. Ann Rheum Dis 2010; 69: 761-5.

4. Legré-Boyer V. Viscosupplementation: techniques, indications, results. Orthop Traumatol Surg Res 2015; 101 (1 Suppl.): S101-8.

5. Abbott T, Altman RD, Dimeff R, et al. Do hyaluronic acid injections delay total knee replacement surgery? ACR 2013 Program Book (Suppl.): 308 Abstract 2139.

6. Romagnoli M, Belmontesi M. Hyaluronic acid-based fillers: theory and practice. Clin Dermatol 2008; 26: 123-59.

7. Sudha PN, Rose MH. Beneficial effects of hyaluronic acid. Adv Food Nutr Res 2014; 72: 137-76.

8. Balazs EA, Denlinger JL. Viscosupplementation: a new concept in the treatment of osteoarthritis. J Rheumatol Suppl. 1993; 39: 3-9.

9. Sudha PN, Rose MH. Beneficial effects of hyaluronic acid. Adv Food Nutr Res 2014; 72: 137-76.
10. Romagnoli M, Belmontesi M. Hyaluronic acid-based fillers: theory and practice. Clin Dermatol 2008; 26: 123-59.

11. Balazs EA. Therapeutic use of hyaluronan. Struct Chem 2009; 20: 341.

12. Wohlrab W, Neubert R, Wohlrab J. Hyaluronsaure und Haut. In: Trends in clinical and experimental dermatology. Wohlrab J (ed.). Shaker Verlag, Aachen 2004; 5-39.

13. Romagnoli M, Belmontesi M. Hyaluronic acid-based fillers: theory and practice. Clin Dermatol 2008; 26: 123-59.

14. Neustadt D, Caldwell J, Bell M, et al. Clinical effects of intraarticular injection of high molecular weight hyaluronan (Orthovisc) in osteoarthritis of the knee: a randomized, controlled, multicenter trial. J Rheumatol 2005; 32: 1928-36.

15. Henrotin Y, Raman R, Richette P, et al. Consensus statement on viscosupplementation with hyaluronic acid for the management of osteoarthritis. Semin Arthritis Rheum 2015; 45: 140-9.

16. Hui AY, McCarty WJ, Masuda K, et al. A systems biology approach to synovial joint lubrication in health, injury, and disease. Wiley Interdiscip Rev Syst Biol Med 2012; 4: 15-37.

17. Rhee DK, Marcelino J, Baker M, et al. The secreted glycoprotein lubricin protects cartilage surfaces and inhibits synovial cell overgrowth. J Clin Invest 2005; 115: 622-31.

18. Ludwig TE, McAllister JR, Lun V, et al. Diminished cartilage-lubricating ability of human osteoarthritic synovial fluid deficient in proteoglycan 4: restoration through proteoglycan 4 supplementation. Arthritis Rheum 2012; 64: 3963-71.

19. Palacio LE, Vitanzo PC. Viscosupplementation. In: Minimally invasive musculoskeletal pain medicine. Freedman M, Morrison WB, Harwood MI (eds.). New York, NY: Informa Healthcare 2007; 53-67.

20. Peter C, Vitanzo Jr, Barry E, et al. Nonsurgical alternatives/conservative management. In: Essentials in total knee arthroplasty. Javad Parvizi (ed.). Brian Klatt, SLACK Incorporated 2011.

21. Caborn D, Rush J, Lanzer W, et al. A randomized, single-blind comparison of the efficacy and tolerability of hylan G-F 20 and triamcinolone hexacetonide in patients with osteoarthritis of the knee. J Rheumatol 2004; 31: 333-43.

22. George E. Intra-articular hyaluronan treatment for osteoarthritis. Ann Rheum Dis 1998; 57: 637-40.

23. Brandt KD, Smith GN Jr, Simon LS. Intraarticular injection of hyaluronan as the treatment for knee osteoarthritis: what is the evidence? Arthritis Rheum 2000; 43: 1192-203.

24. Guidolin DD, Ronchetti IP, Lini E, et al. Morphological analysis of articular cartilage biopsies from a randomized, clinical study comparing the effects of $500-730 \mathrm{kDa}$ sodium hyaluronate (Hyalgan) and methylprednisolone acetate on primary osteoarthritis of the knee. Osteoarthritis Cartilage 2001; 9: 371-81.

25. Moreland LW. Intra-articular hyaluronan (hyaluronic acid) and hylans for the treatment of osteoarthritis: mechanisms of action. Arthritis Res Ther 2003; 5: 54-67.

26. Zhang W, Doherty M, Leeb BF, et al. EULAR evidence based recommendations for the management of hand osteoarthritis: report of a Task Force of the EULAR Standing Committee for International Clinical Studies Including Therapeutics (ESCISIT). Ann Rheum Dis 2007; 66: 377-88. 
27. Berenbaum F, Grifka J, Cazzaniga S, et al. A randomised, double-blind, controlled trial comparing two intra-articular hyaluronic acid preparations differing by their molecular weight in symptomatic knee osteoarthritis. Ann Rheum Dis 2012; 71: 1454-60.

28. Agerup B, Berg P, Akermark C. Non-animal stabilized hyaluronic acid: a new formulation for the treatment of osteoarthritis. BioDrugs 2005; 19: 23-30.

29. Conrozier T. Optimizing the effectiveness of viscosupplementation in non-knee osteoarthritis. Joint Bone Spine 2015 Oct 6. pii: S1297-319X(15)00180-3. doi: 10.1016/j. jbspin.2015.08.009.

30. Roux $\mathrm{CH}$, Euller-Ziegler L, Injections for treatment of carpometacarpal osteoarthritis (rhizarthrosis): what is the evidence? Joint Bone Spine 2015 Oct 6. pii: S1297-319X(15)00167-0. doi: 10.1016/j.jbspin.2015.04.012.

31. Leopold SS, Warme WJ, Pettis PD, et al. Increased frequency of acute local reaction to intra-articular hylan GF-20 (synvisc) in patients receiving more than one course of treatment. J Bone Joint Surg Am 2002; 84-A: 1619-23.

32. Bertucci V, Lynde CB. Current concepts in the use of small-particle hyaluronic acid. Plast Reconstr Surg 2015; 136 (5 Suppl.): 132S-8S.

33. Greene JJ, Sidle DM. The hyaluronic acid fillers: current understanding of the tissue device interface. Facial Plast Surg Clin North Am 2015; 23: 423-32.

34. Cam C, Zhu S, Truong NF, et al. Systematic evaluation of natural scaffolds in cutaneous wound healing. J Mater Chem B Mater Biol Med 2015; 3: 7986-92.

35. Hanc1 D, Altun H. Effectiveness of hyaluronic acid in post-tonsillectomy pain relief and wound healing: a prospective, double-blind, controlled clinical study. Int J Pediatr Otorhinolaryngol 2015; 79: 1388-92.

36. Sayin I, Kaya KH, Ekizoğlu O, et al. A prospective controlled trial comparing spontaneous closure and Epifilm ${ }^{\circledR}$ patching in traumatic tympanic membrane perforations. Eur Arch Otorhinolaryngol 2013; 270: 2857-63.

37. Bruyère $\mathrm{O}$, Cooper $\mathrm{C}$, Pelletier JP, et al. An algorithm recommendation for the management of knee osteoarthritis in Europe and internationally: a report from a task force of the European Society for Clinical and Economic Aspects of Osteoporosis and Osteoarthritis (ESCEO). Semin Arthritis Rheum 2014; 44: 253-63.

38. Moreland LW. Intra-articular hyaluronan (hyaluronic acid) and hylans for the treatment of osteoarthritis: mechanisms of action. Arthritis Res Ther 2003; 5: 54e67.

39. Hochberg MC, Altman RD, April KT, et al. American College of Rheumatology 2012 recommendations for the use of nonpharmacologic and pharmacologic therapies in osteoarthritis of the hand, hip, and knee. Arthritis Care Res 2012; 64: 465-74.

40. Brown GA. AAOS clinical practice guideline: treatment of osteoarthritis of the knee: evidence-based guideline, $2^{\text {nd }} e d$. J Am Acad Orthop Surg 2013; 21: 577-9.

41. Chevalier X. Viscosupplémentation. e-Mem Acad Natl Chir 2012; 11: 040-3.

42. Rutjes AW, Jüni P, da Costa BR, et al. Viscosupplementation for osteoarthritis of the knee: a systematic review and meta-analysis. Ann Intern Med 2012; 157: 180-91.

43. Henrotin Y, Raman R, Richette P, et al. Consensus statement on viscosupplementation with hyaluronic acid for the management of osteoarthritis. Semin Arthritis Rheum 2015; 45: 140-9.
44. Wang CT, Lin J, Chang CJ, et al. Therapeutic effects of hyaluronic acid on osteoarthritis of the knee. A meta-analysis of randomized controlled trials. J Bone Joint Surg Am 2004; 86-A: 538e45.

45. Bellamy N, Campbell J, Robinson V, et al. Viscosupplementation for the treatment of osteoarthritis of the knee. Cochrane Database Syst Rev 2006; 2: CD005321.

46. Lo GH, LaValley M, McAlindon T, et al. Intra-articular hyaluronic acid in treatment of knee osteoarthritis: a metaanalysis. JAMA 2003; 290: 3115e21.

47. Modawal A, Ferrer M, Choi HK, et al. Hyaluronic acid injections relieve knee pain. J Fam Pract 2005; 54: 758e67.

48. Bannuru RR, Natov NS, Dasi UR, et al. Therapeutic trajectory following intra-articular hyaluronic acid injection in knee osteoarthritis: meta-analysis. Osteoarthritis Cartilage 2011; 19: 611-9.

49. Towheed TE, Maxwell L, Judd MG, et al. Acetaminophen for osteoarthritis. Cochrane Database Syst Rev 2006; 1: CD004257.

50. Zhang W, Nuki G, Moskowitz RW, et al. OARSI recommendations for the management of hip and knee osteoarthritis Part III: changes in evidence following systematic cumulative update of research published through January 2009. Osteoarthritis Cartilage 2010; 18: 476e99.

51. Lee C, Hunsche E, Balshaw R, et al. Need for common internal controls when assessing the relative efficacy of pharmacologic agents using a meta-analytic approach: case study of cyclooxygenase 2-selective inhibitors for the treatment of osteoarthritis. Arthritis Rheum 2005; 53 : $510 \mathrm{e} 8$.

52. Arrich J, Piribauer F, Mad P, et al. Intra-articular hyaluronic acid for the treatment of osteoarthritis of the knee: systematic review and metaanalysis. CMAJ 2005; 172: 1039 e43.

53. Medina JM, Thomas A, Denegar CR. Knee osteoarthritis: should your patient opt for hyaluronic acid injection? J Fam Pract 2006; 55: 669e75.

54. Bannuru RR, Vaysbrot EE, Sullivan MC, et al. Relative efficacy of hyaluronic acid in comparison with NSAIDs for knee osteoarthritis: a systematic review and meta-analysis. Semin Arthritis Rheum 2014; 43: 593-9.

55. Campbell J, Bellamy N, Gee T. Differences between systematic reviews/meta-analyses of hyaluronic acid/hyaluronan/hylan in osteoarthritis of the knee. Osteoarthritis Cartilage 2007; 15: 1424-36.

56. Conrozier T. Optimizing the effectiveness of viscosupplementation in non-knee osteoarthritis. Joint Bone Spine 2015 Oct 6. pii: S1297-319X(15)00180-3. doi: 10.1016/j. jbspin.2015.08.009.

57. Noël E, Hardy P, Hagena FW, et al. Efficacy and safety of Hylan G-F 20 in shoulder osteoarthritis with an intact rotator cuff. Open-label prospective multicenter study. Joint Bone Spine 2009; 76: 670-3.

58. Kwon YW, Eisenberg G, Zuckerman JD. Sodium hyaluronate for the treatment of chronic shoulder pain associated with glenohumeral osteoarthritis: a multicenter, randomized, double-blind, placebo-controlled trial. J Shoulder Elbow Surg 2013; 22: 584-94.

59. Blaine T, Moskowitz R, Udell J, et al. Treatment of persistent shoulder pain with sodium hyaluronate: a randomized, controlled trial. A multicenter study. J Bone Joint Surg Am 2008; 90: 970-9. 
60. Kwon YW, Eisenberg G, Zuckerman JD. Sodium hyaluronate for the treatment of chronic shoulder pain associated with glenohumeral osteoarthritis: a multicenter, randomized, double-blind, placebo-controlled trial. J Shoulder Elbow Surg 2013; 22: 584-94.

61. Colen S, Geervliet P, Haverkamp D, et al. Intra-articular infiltration therapy for patients with glenohumeral osteoarthritis: a systematic review of the literature. Int J Shoulder Surg 2014; 8: 114-21.

62. Colen S, Haverkamp D, Mulier M, et al. Hyaluronic acid for the treatment of osteoarthritis in all joints except the knee: what is the current evidence? BioDrugs 2012; 26 : 101-12.

63. Manara M, Bortoluzzi A, Favero M, et al. Italian Society for Rheumatology recommendations for the management of hand osteoarthritis. Reumatismo 2013; 65: 167-85.

64. Fuchs S, Mönikes R, Wohlmeiner A, et al. Intra-articular hyaluronic acid compared with corticoid injections for the treatment of rhizarthrosis. Osteoarthritis Cartilage 2006; 14: 82-8.

65. Hochberg MC, Altman RD, April KT, et al. American College of Rheumatology 2012 recommendations for the use of nonpharmacologic and pharmacologic therapies in osteoarthritis of the hand, hip, and knee. Arthritis Care Res 2012; 64: 465-74.

66. Trellu S, Dadoun S, Berenbaum F, et al. Intra-articular injections in tumb osteoarthritis: systematic review and meta-analysis of randomized controlled trials Joint Bone Spine 2015, http://dx.doi.org/10.1016/j. jbspin.2015.02.002

67. Roux $\mathrm{CH}$, Euller-Ziegler L. Injections for treatment of carpometacarpal osteoarthritis (rhizarthrosis): what is the evidence? Joint Bone Spine 2015 Oct 6. pii: S1297-319X(15)00167-0. doi: 10.1016/j.jbspin.2015.04.012.

68. Conrozier T, Couris CM, Mathieu P, et al. Safety, efficacy and predictive factors of efficacy of a single intra-articular injection of non-animal-stabilized hyaluronic acid in the hip joint: results of a standardized follow-up of patient treated for hip osteoarthritis in daily practice. Arch Orthop Trauma Surg 2009; 129: 843-8.

69. Atchia I, Kane D, Reed MR, et al. Efficacy of a single ultrasound-guided injection for the treatment of hip osteoarthritis. Ann Rheum Dis 2011; 70: 110-6.

70. Henrotin Y, Raman R, Richette P, et al. Consensus statement on viscosupplementation with hyaluronic acid for the management of osteoarthritis. Semin Arthritis Rheum 2015; 45: 140-9.

71. Fernández López JC, Ruano-Ravina A. Efficacy and safety of intraarticular hyaluronic acid in the treatment of hip osteoarthritis: a systematic review. Osteoarthritis Cartilage 2006; 14: 1306-11.

72. Qvistgaard E, Christensen R, Torp-Pedersen S, et al. Intra-articular treatment of hip osteoarthritis: a randomized trial of hyaluronic acid, corticosteroid, and isotonic saline. Osteoarthritis Cartilage 2006; 14: 163-70.

73. Rivera F. Single intra-articular injection of high molecular weight hyaluronic acid for hip osteoarthritis. J Orthop Traumatol 2015 Oct 8. [Epub ahead of print].

74. Sun SF, Chou YJ, Hsu CW, et al. Efficacy of intra-articular hyaluronic acid in patients with osteoarthritis of the ankle: a prospective study. Osteoarthritis Cartilage 2006; 14: 867-74.
75. Witteveen AG, Hofstad CJ, Kerkhoffs GM. Hyaluronic acid and other conservative treatment options for osteoarthritis of the ankle. Cochrane Database Syst Rev 2015; 10: CD010643.

\section{Address for correspondence:}

\section{Andrzej Kotela MD, PhD}

Department of Orthopaedics and Traumatology

of Musculoskeletal System

$1^{\text {st }}$ Faculty of Medicine

Medical University of Warsaw

ul. Lindleya 4, 02-005 Warsaw, Poland

Phone: +48 661166440

E-mail: andrzejkotela@op.pl 